\title{
ZAGREB OČIMA MEĐUNARODNIH MIGRANATA: ZNAČENJA, POTENCIJALI I (RE)SKALIRANJA GRADA
}

JASNA ČAPO

Institut za etnologiju i folkloristiku

Šubićeva 42, Zagreb

capo@ief.hr

iD orcid.org/0000-0001-6181-2860

PETRA KELEMEN

Filozofski fakultet Sveučilišta u Zagrebu

Odsjek za etnologiju i kulturnu antropologiju

Ivana Lučića 3, Zagreb

pkelemen@ffzg.hr

iD orcid.org/0000-0002-3372-8175
DOI: $10.17234 /$ SEC.29.9

Izvorni znanstveni rad

Primljeno: 6. 9. 2017.

Prihvaćeno: 9. 10. 2017.

Ovaj rad nalazi se u otvorenom pristupu i može se distribuirati u skladu s odredbama licencije CC BY-NC-ND 4.0 HR

Uklapajući se u migracijska istraživanja koja se zanimaju za načine na koje migranti nalaze svoje mjesto u gradovima naseljavanja te pridonose njihovu (re)skaliranju, rad se bavi značenjima grada koja konstruiraju međunarodni migranti srednjih društvenih slojeva u Zagrebu. Pritom se analizira kako, na osnovi atributa koje pridaju Zagrebu i usporedbama s drugim gradovima, migranti Zagreb pozicioniraju na vlastitim skalama gradova. Te se individualne ocjene promatraju u odnosu prema poziciji koju Zagreb ima kao migracijsko odredište na temelju određenih gospodarskih $i$ društvenih pokazatelja. Rad se dotiče i potencijala migranata $u$ repozicioniranju ili reskaliranju grada unutar globalnih urbanih hijerarhija.

Ključne riječi: međunarodne migracije, urbana antropologija, Zagreb, skaliranje grada

\section{MIGRANTI I GRAD ${ }^{1}$}

"Grad je i okolina i rezultat ljudskog djelovanja, uključujući djelovanje transnacionalnih migranata, njihovih mreža i njihovih projekata." (Smith i Eade 2009:12)

${ }^{1}$ Članak je nastao u okviru projekta Stvaranje grada: prostor, kultura i identitet (br. 2350, financira se sredstvima Hrvatske zaklade za znanost), www.citymaking.eu. 
Karakteristike su suvremene mobilnosti različiti, složeni i isprepleteni višestrukimotiviinamjere, kaoigradacije dobrovoljnostiinedobrovoljnosti. ${ }^{2}$ Izbjeglice i tražitelji azila, uz ekonomske migrante, predmet su razmatranja mnogobrojnih znanstveno-stručnih analiza, a ujedno su nezaobilazno mjesto i javnog i političkog diskursa i retorika nacionalnih država. No, obrasci mobilnosti znatno su širi od izbjegličkih i klasičnijih ekonomskih i obiteljskih migracija (Favell et al. 2009). Svjedočimo intenzivnoj mobilnosti osoba s vrha društvene stratifikacije: korporativnih menadžera, financijskih elita, zaposlenika međunarodnih organizacija, putujućih informacijskih stručnjaka - u stručnoj literaturi klasificiranih kao "visokostručni migranti", "transnacionalne elite" ili "transnacionalna kapitalistička klasa". Njih se smatra paradigmatskim pokretačima globalizacije (Andreotti et al. 2015; Beaverstock 2005; Fechter 2007; Meier 2015; Nowicka 2006).

Između elitnih i deprivilegiranih migranata nalaze se osobe "skromnijeg blagostanja" koje raspolažu resursima "novca, vremena ili obrazovanja" koji im omogućavaju mobilnost (Amit 2007). Oni odražavaju širenje mogućnosti mobilnosti na srednje klase (Amit 2007; Favell et al. 2009). Među njima su studenti, ambiciozni ili pustolovni pripadnici srednje klase koji teže socijalnoj pokretljivosti (Favell et al. 2009), stručnjaci raznih profila koji koriste mogućnosti slobodnog protoka ljudi u Europskoj uniji (Favell 2008) i migranti svih dobnih skupina koji se privremeno ili stalno naseljavaju u mjestima koja za njih predstavljaju vrijednost "bolje kvalitete života” ili “životnog stila” (Benson i O’Reilly 2009).

Ovaj je rad prilog istraživanjima međunarodne migracije srednjih društvenih slojeva u grad Zagreb. ${ }^{3}$ Niže u radu opisujemo osnovna obilježja migranata koji su u središtu našeg zanimanja, no pritom dalje u tekstu sugovornike ne smještamo unutar određenih statusnih kategorija i/ili istraživačkih koncepata u istraživanjima migracija (npr. obiteljske, radne,

\footnotetext{
${ }^{2}$ Pritom nemaju svi jednake mogućnosti mobilnosti; fizičke i simboličke granice pojedincima, osobito onima na rubu društvene i ekonomske ljestvice, smanjuju ili posve oduzimaju tu mogućnost. Mobilnost stoga ne vidimo kao neproblematičnu i posve pozitivnu te se zalažemo za kritički pristup ovom konceptu (usp. Grgurinović 2013).

${ }^{3}$ Turisti, koji su u potrazi za razonodom, dokolicom i odmorom, egzemplarno mobilne osobe iz srednjih društvenih slojeva, nisu dio naših razmatranja, nego je riječ o osobama koje se na određeno vrijeme doseljavaju u grad.
} 
visokokvalificirane, studentske migracije, migracije životnog stila i sl.). Zadržavamo se samo na zajedničkom obilježju naših sugovornika kao dobrovoljnih međunarodnih migranata srednjih društvenih slojeva, čime želimo naglasiti da je riječ o heterogenoj migrantskoj populaciji koja izmiče jednoznačnom svrstavanju u kategorije.

Posljednjih nekoliko godina u fokusu je migracijskih istraživanja teorijsko povezivanje neoliberalnih globalnih procesa, mjesta imigracije i inkorporacije migranata ili načina na koje se migranti upisuju u mjestima naseljavanja, najčešće gradovima (usp. Glick Schiller i Çağlar 2009, 2011, 2013). Namjera je tih istraživanja konkretna mjesta, koja su ostajala izvan istraživačkog fokusa ili su bila svedena tek na puki kontekst migracija (Glick Schiller 2012:886), postaviti u središte razmatranja. Mjestima se pritom ne pristupa kao "kontejnerima" nego je pozornost usmjerena na urbano restrukturiranje i uloge migranata u tom procesu (Çağlar i Glick Schiller 2011:19). Migrantska inkorporacija ${ }^{4}$ proučava se u kontekstu, s jedne strane, pozicioniranja i planova za repozicioniranje gradova na skali globalnih hijerarhija urbane moći i, s druge, globalnog, postindustrijskog, neoliberalnog restrukturiranja kapitala i posljedica koje taj proces ima na gradove i migracije. Teoretičari definiraju "gradsku skalu" kao različito pozicioniranje gradova u relaciji spram drugih gradova unutar nacionalnog, regionalnog i globalnog prostora. Ono je oblikovano artikulacijom institucionalne, političke, kulturne i ekonomske moći grada (Glick Schiller i Çağlar 2009, 2011). Migranti se u toj trijadi globalnog kapitala-mjesta-migracija poimaju kao stanovnici gradova, ali i kao stvaratelji urbanih skala, dakle kao akteri transformacija i repozicioniranja grada u globalnim hijerarhijama moći: "[B]iti stanovnik grada znači živjeti u gradu, doprinositi globalnim procesima koji oblikuju urbanu ekonomiju, politike i kulturu i propitivati te procese" (Çağlar i Glick Schiller 2011:19). Njihova uloga varira u odnosu na različito pozicioniranje grada.

Na opisanom tragu nastalo je i naše istraživanje inozemnih migranata u Zagrebu. Zanimalo nas je kako osobe koje su doselile u Zagreb, da bi u njemu privremeno ili trajnije živjele, aktivno pridonose gradskom životu i trenutačnom restrukturiranju grada. Ujedno nas je zanimalo i koja značenja grada konstruiraju, kako u nj smještaju svoja iskustva, sjećanja i planove,

\footnotetext{
${ }^{4}$ Konceptu "integracija” preferiramo termin “inkorporacija” jer je manje podložan političkoj retorici (usp. Glick Schiller i Çağlar 2009:179).
} 
vežu određena razdoblja svoga života i lokaliziraju svoje prakse bivanja i pripadanja (usp. Levitt i Glick Schiller 2004).

U sljedećem odjeljku, nakon kratkog osvrta na za naše istraživanje relevantna demografska i gospodarska obilježja grada Zagreba, prezentiramo konceptualni okvir i istraživačka pitanja te osnovna obilježja međunarodnih migranata koji su predmet analize. Središnji dio kroz tri analitička sklopa opisuje koja značenja međunarodni migranti pridaju gradu i kako se inkorporiraju u grad u kontekstu gradskih gospodarskih pokazatelja. Analiza pokazuje da su inozemni doseljenici koji se trajnije doseljavaju u grad stvaratelji i akteri gradskih transformacija, a time i preoznačitelji pozicije Zagreba u međunarodnoj urbanoj hijerarhiji. Premda imaju potencijal da budu konstitutivni dio gradskih napora na repozicioniranju grada unutar globalnih urbanih hijerarhija, zaključak utvrđuje da kao takvi nisu prepoznati.

\section{ZAGREB I MEDUNARODNE MIGRACIJE- KONTEKSTUALNI I METODOLOŠKI OKVIR ISTRAŽIVANJA}

Hrvatska i Zagreb zauzimaju nisku poziciju na karti međunarodnih migracija i transnacionalnih i globalnih investicija. Na to upućuju i istodobno objašnjavaju zašto je tomu tako pojedini demografski i gospodarski pokazatelji.

Na godišnjoj razini broj ljudi koji doseljavaju u Zagreb iz inozemstva nije velik: posljednjih deset godina on se uglavnom, izuzev dviju godina kada je bio manji, kretao između dvije i tri tisuće; 2016. godine broj je doseljenih bio najviši: 3330 (Gradski ured za strategijsko planiranje i razvoj Grada 2016:92; Državni zavod za statistiku 2017; usp. Gradski ured za strategijsko planiranje i razvoj Grada 2015a). ${ }^{5}$ Od ukupno 790017

\footnotetext{
${ }^{5}$ Migracijski je saldo s inozemstvom, nakon blage pozitive početkom desetljeća, negativan: 2015. godine 2288 više osoba napustilo je Zagreb i otišlo u inozemstvo nego što ih je iz inozemstva došlo, dok za 2016. godinu taj broj iznosi 1546 (Gradski ured za strategijsko planiranje i razvoj Grada 2016:92; Državni zavod za statistiku 2017). Moguće je da jedan dio doseljenika izmiče statističkom nadzoru, posebice ako se dulje ne zadržavaju. Iz nekih je Facebook rasprava migranata vidljivo da se mnogi ne prijavljuju, koristeći mogućnost da u zemlji bez prijave borave do 90 dana.
} 
stanovnika Zagreba 2011. godine samo je njih 4871 s isključivo stranim državljanstvom, a 15586 osoba s dvojnim, hrvatskim i inim državljanstvom (Gradski ured za strategijsko planiranje i razvoj Grada 2016:74-75). ${ }^{6}$

Niz je gospodarskih čimbenika koji utječu na slab dolazak inozemnih migranata iako je Zagreb najjače gospodarsko središte Hrvatske i u njemu se ostvaruje trećina nacionalnog BDP-a. Nakon podrobne analize stanja zagrebačkog gospodarstva koje pokazuje negativan trend restrukturiranja, ${ }^{7}$ studija Ekonomskog instituta u Zagrebu nabraja niz razvojnih problema grada; između ostalih, a relevantno za naše istraživanje međunarodnih migranata u Zagrebu, to su niski BDP po stanovniku u usporedbi sa sličnim gradovima u EU-u, nedovoljna konkurentnost u odnosu na druge gradove, razvoj nedovoljno zasnovan na tehnologiji i inovacijama, nedostatni poticaji korištenja znanja, tehnologije i razvoja inovacija kod malih i srednjih poduzetnika, nedovoljna orijentiranost na inozemna tržišta, nedovoljna podrška razvoju poduzetničke infrastrukture, itd. (Ekonomski institut 2016:76).

Uz navedene nepovoljne gospodarske čimbenike, dodatan aspekt koji treba uzeti u obzir u promatranju privlačnosti Zagreba - i općenito Hrvatske - kao migracijskog odredišta tiče se nacionalnih propisa, kao što su visoki porezi, te restriktivnih zakonskih obveza pri pokretanju poduzeća za strance. ${ }^{8}$ Bitan je čimbenik u promatranju položaja Zagreba i Hrvatske

\footnotetext{
${ }^{6}$ 93\% stanovnika Zagreba jesu Hrvati, 99\% ima hrvatsko državljanstvo, $82 \%$ je rođeno u Hrvatskoj, a oko 50\% u Zagrebu. Od 18\% rođenih izvan Hrvatske jedna trećina ili oko 48 000 doseljeno je iz drugih država osim država sljednica bivše Jugoslavije. Gotovo polovica toga broja jesu osobe doseljene iz Njemačke, no riječ je, uostalom kao i među useljenicima iz skupine "ostalih", nespecificiranih zemalja, uglavnom o Hrvatima povratnicima iz inozemstva i njihovim potomcima, o čemu govori navedeni broj osoba s isključivo stranim državljanstvom i osoba s dvojnim državljanstvom (Gradski ured za strategijsko planiranje i razvoj Grada 2016:74-75).

${ }^{7}$ Negativan trend restrukturiranja očituje se u smanjenju zaposlenosti u sekundarnim djelatnostima (posebno u industriji i građevinarstvu) i u porastu zaposlenosti u uslužnim djelatnostima (financijske, trgovinske, komunikacijske) (Ekonomski institut 2016:34-38, 96). Studija je nastala na osnovi podataka do kraja 2014. godine.

${ }^{8}$ Vidi Zakon o strancima (NN 130/2011, http://narodne-novine.nn.hr/clanci/ sluzbeni/2011_11_130_2600.html; NN 74/2013, http://narodne-novine.nn.hr/clanci/ sluzbeni/2013_06_74_1475.html). Npr. u članku 78, između ostaloga, od državljana
} 
na karti međunarodnih migracijskih tokova i činjenica nepostojanja državne i gradske migracijske politike kao referentnoga političkog okvira za migracijske procese. ${ }^{9}$

Navedeni gospodarski aspekti Zagreb pozicioniraju nisko na komparativnoj skali moći europskih i svjetskih gradova. Unazad nekoliko godina, Zagreb je kroz razvoj turističke industrije prionuo repozicioniranju ili reskaliranju svoga statusa unutar globalnih hijerarhija urbane moći. Temeljni je cilj tih nastojanja pozicionirati Zagreb kao "novu srednjoeuropsku turističku destinaciju s definiranim imidžem/identitetom" (Gradski ured za strategijsko planiranje i razvoj Grada 2012:23). ${ }^{10}$ Turizam pritom nije samo "razvojna poluga", nego je definiran i "kao medij globalne prezentacije [...] identiteta i dostignuća” Zagreba (Horwath HTL 2016).

Premda je grad time usmjeren na privlačenje turista, a ne na trajnije oblike doseljavanja mobilnih ljudi iz inozemstva, usporedno s ovim pokušajima turističkog repozicioniranja Zagreba, i zagrebačka inozemna migrantska scena čini se u posljednje vrijeme nešto živahnijom. Na to bi uputile opaske naših sugovornika, međunarodnih migranata, kao i broj članova Facebook grupe Expats in Zagreb (Migranti u Zagrebu), ${ }^{11}$ koji je od rujna 2016. do srpnja 2017. godine porastao za oko 1000, te obuhvaća

država izvan EU-a očekuje se zapošljavanje hrvatskih državljana proporcionalno broju zaposlenih stranaca u trgovačkom društvu ili obrtu registriranom u Hrvatskoj. Na taj članak Zakona referiralo se nekoliko međunarodnih migranata, ocijenivši ga proizvoljnim i neprimjerenim tipu i veličini obrta koji su otvorili. O visokim porezima također su se negativno izrazili.

${ }^{9} \mathrm{Na}$ državnoj razini posljednja migracijska politika donesena je 2013. godine i odnosila se na razdoblje od 2013. do 2015. godine (Migracijska politika Republike Hrvatske za razdoblje 2013. - 2015. godine, NN 27/2013, http://narodne-novine.nn.hr/clanci/sluzbeni/ full/2013_03_27_456.html). Gradska migracijska politika nije dio Nacrta Strategije razvoja Urbane aglomeracije Zagreb iz 2017. godine (Gradski ured za strategijsko planiranje i razvoj Grada 2017).

${ }^{10}$ Razvoj turizma definiran je, naime, kao jedna od mjera u strateškom cilju konkurentnog gospodarstva i viđen kao "potencijal rasta, izvora blagostanja, urbane regeneracije i rasta kvalitete života vlastitih stanovnika" (Gradski ured za strategijsko planiranje i razvoj Grada 2012:23; usp. ibid. 2015b). O naporima pozicioniranja grada govori i rad na brendiranju Zagreba: Horwath HTL 2011.

${ }^{11}$ Grupa je u međuvremenu, nakon našeg istraživanja, promijenila naziv u Expats in Zagreb [Official]. 
oko 2400 osoba. Riječ je o značajnom porastu sudionika društvene mreže koja postoji desetak godina i mjesto je virtualnog okupljanja i razmjene informacija inozemnih doseljenika u grad.

Provodnu nit našeg istraživanja čini pitanje: kako međunarodni migranti praktično, tjelesno, materijalno, emocionalno i kognitivno oblikuju trenutačno mjesto svoga življenja - grad Zagreb - i svoje mjesto u njemu? ${ }^{12}$ Pritom smo pozornost posvetile i tomu kako migranti grade odnos dvaju ili više gradova njihova života. Naime, zahvaljujući iskustvu života u više sredina migranti mogu svoja urbana iskustva komparativno sagledati. Njihovo preseljenje tako može biti obilježeno osjećajima novosti, neizvjesnosti, frustriranost zbog nedostatka nečega, oduševljenosti zbog prisutnosti nečega, a takve percepcije izrastaju iz komparativnog pogleda na bivše sredine njihova života. Naša je pozornost bila usmjerena na to koju poziciju, i na osnovi kojih atributa, Zagreb zauzima u takvim odmjeravanjima.

Podatke o migrantima prikupile smo sudioničkim promatranjem, u neformalnim razgovorima i susretima s njima u privatnim i javnim kontekstima (npr. prilikom susreta koje organiziraju Facebook grupe), pri posjetima migrantskim biznisima, te istraživanjem objava u Facebook grupama Expats in Zagreb i Internationals living in Croatia (Stranci koji žive u Hrvatskoj). Njihovi su članovi pretežito međunarodni doseljenici i Hrvati remigranti u prvoj i drugim generacijama. Analizirale smo i sadržaj portala Unique Zagreb (Jedinstveni Zagreb), ${ }^{13}$ nekoliko blogova migranata u Zagrebu ${ }^{14}$ te niz medijskih prikaza. ${ }^{15}$ Ključne informacije na kojima se

\footnotetext{
${ }^{12}$ Migrante promatramo kao aktere stvaranja grada, složenog i kontekstualno uvjetovanog procesa. Stvaranje grada temeljni je koncept znanstvenog projekta Stvaranje grada: prostor, kultura i identitet, u okviru kojeg je nastao ovaj rad (vidi bilješku 1).

${ }^{13} \mathrm{http} / /$ www.uniquezagreb.com, osnivačica portala jest Theresa Khalil.

${ }^{14}$ Jedan je imao i knjiško izdanje, na engleskom i hrvatskom jeziku: McClain Brown 2016.

${ }^{15}$ Pratile smo portrete migranata iz pera novinara Tihomira Dujmovića (https://www. tportal.hr/tag/lijepa-nasa-vasa, objavljuju se od 2013. godine) i televizijski serijal istog autora Lijepa vaša, te analizirale dokumentarni film Stranci, a naši Josipa Šarića iz 2015. godine (https://hrti.hrt.hr/video/show/1788560/stranci-a-nasi-dokumentarni-film). Daniel Rodríguez Kargacin, Venezuelanac hrvatskog podrijetla koji živi u Zagrebu, intervjuirao je nekoliko migranata za seriju videa u sklopu projekta Kiosk (https://www.youtube.com/ channel/UCwwaMYUbsqSFffxYlpV9_6w). Analiza navedenih tiskanih, internetskih i medijskih materijala premašila bi opseg ovog rada.
} 
temelji ovaj rad dobile smo od tridesetak doseljenika, muškaraca i žena, s kojima smo, uglavnom na engleskom jeziku, obavile opsežne, ponekad i višekratne, polustrukturirane intervjue o motivima njihova doseljenja $u$ Zagreb, radu i životu u gradu, viđenju grada i sl. Dio tih razgovora vodio je bilježenju cjelokupne migracijske i životne priče.

Naši su sugovornici heterogena i hibridna skupina ljudi iz srednjega društvenog sloja. Prema motivima dolaska, oni su studenti i profesori na akademskoj mobilnosti, menadžeri i njihovi partneri, diplomati, mali i srednji poduzetnici, obiteljski migranti (osobe koje doseljavaju iz obiteljskih razloga, tj. zbog veze s hrvatskim partnerom/partnericom), remigranti iz hrvatske dijaspore u prvoj i kasnijim generacijama koji se zbog osjećaja pripadnosti, s ciljem učenja hrvatskoga, iz avanturizma ili ljubavi prema lokalnom partneru, ${ }^{16}$ naseljavaju u Zagrebu. Među našim sugovornicima pretežu obiteljski migranti i remigranti; analize Facebook grupa također upućuju na dominaciju obiteljskih migranata među međunarodnim migrantima u Zagrebu. ${ }^{17}$ Uglavnom je riječ o mlađim i o osobama u ranim srednjim godinama, između 20 i 40 godina, s fakultetskim obrazovanjem (ili u procesu njegova stjecanja) i zanimanjima u rasponu od inženjera računarstva, web-dizajnera, marketinških stručnjaka, biznismena, do profesora jezika, novinara i umjetnika. Raznolike su zemlje iz kojih dolaze ili u kojima su živjeli: neka od zemalja Europske unije (Njemačka, Austrija, Francuska, Poljska, Španjolska, Ujedinjeno Kraljevstvo, Belgija) ili izvan EU-a - Ukrajina, SAD, Kanada, Jamajka, Grenada, Venezuela, Argentina, Japan, Egipat, Obala Bjelokosti, Australija, Južnoafrička Republika, Peru, Šri Lanka itd. Manje-više svi imaju bogato iskustvo mobilnosti i tijekom života nekoliko su puta mijenjali mjesto boravka. U Zagrebu žive u rasponu od nekoliko mjeseci do deset godina; temeljem različitih pravnih statusa (ovisno o tome imaju li hrvatske pretke, dolaze li putem obiteljske migracije i/ili s poduzetničkim namjerama, kao studenti itd.).

\footnotetext{
${ }^{16}$ Povratnici (remigranti) i potomci hrvatskih iseljenika u nekoliko generacija uključeni su u ovo istraživanje. S drugim međunarodnim imigrantima zajedničko im je iskustvo života u drugim zemljama, transnacionalne veze, neki razlozi doseljavanja, poduzetnički duh i aktivno uključivanje u gospodarske i društvene proces. Usp. Čapo 2012; Hornstein Tomić 2014.

${ }^{17}$ To je, čini se, dominantan motiv doseljavanja u Zagreb i u Hrvatsku (usp. Čapo, u tisku).
} 
Raznorodnost njihova nacionalnog i etno-kulturnog podrijetla, motiva i puteva dolaska u Zagreb, pravnog statusa koji uživaju u Hrvatskoj, visoka razina obrazovanja i stručnosti "simptomatični" su za rastuću različitost suvremenih obrazaca međunarodnih migracija (Conradson i Latham 2005:288). Unatoč nekim zajedničkim karakteristikama (dob, razina obrazovanja, pripadnost srednjim slojevima u zemljama podrijetla), mogle bismo reći kako je riječ o "superrazličitoj" (usp. Vertovec 2007) skupini osoba. Upravo zato ih ne želimo svesti na bilo koji od poznatih migrantskih "tipova" i "kategorija" kao što su visokostručni, elitni, obiteljski migranti, migranti životnog stila itd. Kategoriziranje bi reduciralo i simplificiralo složene, hibridne aspekte njihove migracije u Zagreb na jedan od njezinih aspekata, bio to motiv dolaska, pripadnost visokokvalificiranim skupinama, hrvatsko podrijetlo ili, nakon određena razdoblja života u Zagrebu, otkrivanje grada kao poželjne destinacije zbog njegova "životnog stila" i sl. Sve to zajedno čini složeni splet obilježja promatranih migranata. Isprepletenost različitih međuovisnih varijabli u svakom pojedinom slučaju rezultira raznolikim migrantskim iskustvima, doživljajima i putevima inkorporacije u Zagrebu. Gdje se te varijable preklapaju, nastaju i slična iskustva o čemu govorimo u nastavku.

\section{MIGRANTI KONSTRUIRAJU ZNAČENJA GRADA Promjenjiva značenja grada}

Međunarodni migranti gradu pripisuju niz značenja. Kreirana su u njihovim susretima s materijalnošću i estetikom grada (Frers i Meier 2007) i s njegovim stanovnicima. Svojim aktivnostima i praksama u gradu migranti proizvode specifična značenja i slike grada vezano uz svoje podrijetlo, mjesta prethodnog života, socijalne identitete, dob i razlog dolaska i nastanjivanja u Zagrebu. Grad se također oslikava i ispunjava značenjima u relaciji i kontrastu spram drugih mjesta i gradova u kojima je osoba živjela. Osoba može imati više perspektiva o Zagrebu, usporedno ili sukcesivno; one se protokom vremena razvijaju, mijenjaju i produbljuju ovisno o osobnim interesima i o tome koliko se osoba želi ili uspijeva investirati u grad i društvo. Stoga su značenja i slike grada dinamične, a ne statične.

Kako se produbljuje poznavanje grada i stječe iskustvo života u gradu, tako se mijenja i fokus odnosno perspektiva grada: od početnoga 
"praznog mjesta" (Bauman 2000), mjesta koje doseljeniku mnogo ne govori i s kojim teško uspostavlja kontakt, grad dobiva neke pozitivne predznake i postaje prihvatljivim mjestom življenja. Stigavši zimi, jedan se doseljenik u okruženju "sivih zagrebačkih fasada iscrtanih grafitima", nakon razgledavanja donjogradskih stanova opremljenih "staromodnim i debelim" namještajem "koji bi imala [njegova] baka" i prvih uvida u "izazove" društvenog i poduzetničkog života osjećao loše. Imao je osjećaj neadekvatnosti i projicirao ga je na "hladno i arogantno" domaće stanovništvo tvrdeći da je ono manje spremno prihvatiti došljake nego u gradovima kao što su San Francisco i London. Nakon godine dana, zamijenio ga je osjećaj sviđanja, prihvaćenosti, familijarnosti s prostorom i ljudima i pripadanja susjedstvu. Ujedno se navodno promijenio i odnos lokalnog stanovništva prema njemu, te naš sugovornik sudi da je lokalnom stanovništvu danas, dvije godine nakon njegova dolaska, "potpuno transparentan", tj. nevidljiv, premda zbog svoga afričkog podrijetla pripada vidljivim i izrazito malobrojnim migrantima:

"Kad sam došao ovamo, osjećao sam se kao autsajder. Sad kad ovdje živim, ne bih rekao da se osjećam kao kod kuće, ali [grad] mi je definitivno postao simpatičniji. Bio je to proces. Nakon jedne godine postao mi je simpatičniji. (...) Sad mi se sviđa i počeo mi se sve više sviđati. I vjerojatno ću se osjećati sve ugodnije. (...) U početku su ljudi bili prilično hladni. U početku sam se osjećao kao autsajder i mislio sam da me ljudi ne prihvaćaju. Bio sam skoro paranoičan, mislio sam: 'Ljudi se vjerojatno pitaju što ovaj tip tu radi.' Tako je bilo na početku. Danas mislim da sam u potpunosti dio susjedstva. U pekari me znadu. Kao da je na mojem čelu napisano: 'Ja sam iz susjedstva.' Tako da su i reakcije ljudi drukčije. Ja se osjećam ugodno i takvu sliku projiciram."

$\mathrm{U}$ ovom iskazu razvidna je procesnost upisivanja značenja u mjesto života s jedne strane te, s druge, isprepletenost osobne perspektive i stanja s materijalnošću grada koja, pritom, nije ostavljala pozitivan dojam. Migrant je vlastite osjećaje, izazvane nezadovoljstvom zbog neplaniranog i donekle nevoljkog preseljenja iz San Francisca u Zagreb, projicirao na grad i njegovo stanovništvo. Iščitavao je grad i stanovnike iz određene perspektive, oboje u početku konstruirajući kao nezanimljive i nesimpatične. S vremenom, kako 
je unajmio ugodan moderan stan u širem centru, stekao prijatelje, upoznao grad kao pješak i korisnik javnog prijevoza, pronašao zadovoljavajuću gradsku nišu i uskladio svoje potrebe s ritmom i ponudom grada, osjetio se "od", a ne "izvan" mjesta.

Drugi naš sugovornik prisjeća se kako se po dolasku u Hrvatsku, koja nije bila njegov prvi izbor pri odlasku iz vlastite nesigurne i socijalnim problemima obilježene zemlje, pitao gdje se to našao te je tek nakon nekoliko dana otišao do centra grada. Tada je počeo pješačiti po gradu i tako ga upoznavati. I danas na taj način svakodnevno traži lijepe motive za fotografiranje kojim se bavi. Postupno, kako je sve više upoznavao grad i ljude, počeo se osjećati kao "kod kuće”. Danas, nakon dvije i pol godine života u Zagrebu, smatra kako mnogo više razumije ljude, mnogo je čitao o povijesti te i nju bolje razumije, upoznat je s aktualnim političkim i društvenim događajima, a sam je grad vrlo dobro upoznao. Slično postupno upoznavanje različitih gradskih lokacija kao važno u stvaranju osjećaja pripadanja gradu javlja se i u iskazima drugih migranata.

Dužim boravljenjem u dijelu grada u kojem živi i radi osoba razvija mikrolokalnu perspektivu i osjećaj ugode svjedočeći kako i migranti kao i nemigrantsko stanovništvo u gradu žive lokalno (usp. Gulin Zrnić 2009). Uz mjesto stanovanja, najčešće širi centar i, za imućnije i osobe u diplomaciji sjeverni obronci grada, migranti najbolje upoznaju središte grada. Upoznaju i druge dijelove, osobito ako nude rekreativne mogućnosti ili prilike za društvenost:

"Dakle, to je ugodan grad. Trebalo mi je malo vremena da se počnem osjećati ugodno, kao kod kuće, sigurno, što god to značilo. Moj je dom gdje se osjećam ugodno, ugodna mjesta, gdje se osjećam ugodno. Imao sam takav energetski udar, ili kako god to nazivaš, jednom kad sam prošao Britancem jer je on doista moj kvart.”

"Mislim da bih rekla [da je Zagreb] dom. Kad sam išla u Beč i vratila se, bila sam u tramvaju i pomislila: 'Konačno, konačno u svojem Zagrebu, u svojemu starom tramvaju koji mi se, zapravo, sviđa."”

Sinergija osobnoga i materijalnosti mjesta i njihovi promjenjivi odnosi prisutni su kod svih doseljenika, uglavnom se razvijajući u pozitivnom smjeru. Kako je to zgodno kazala jedna sugovornica: "Nakon nekog 
vremena počneš voljeti mjesto u kojem živiš, ono je tvoj dom.” Doseljenici u Zagreb koji tu namjeravaju dulje živjeti posebno cijene kad osjete da ih se prepoznaje i tretira "našima" kroz male privilegije i poznavanje njihovih navika. To je ujedno i znak da pripadaju, da su se uspješno inkorporirali u gradske prostore i društvene mreže:

"To je mali viski-bar. Imaju izvrstan izbor viskija i cigara. Kad idem s prijateljima, volim tamo sjesti. (...) I kako sam tamo često, znam ljude. Osjećam se kao doma. Nije da mi kažu: 'Dobar dan, gospodine!' To je više: 'Eee, di si?' - 'Tu sam!' Ideš na isto mjesto i osjećaš se kao doma. A oni već znaju koji viski najviše volim. Prošli su put imali malo u boci i stavili su je na stranu jer znaju da ću doći. To mi je nedostajalo u Parizu i Berlinu, tamo je sve taaako anonimno!"

Mnoštvo migrantskih iskustava grada analizirale smo kroz tri analitička sklopa: prvi se tiče materijalnosti i estetike grada, drugi je usmjeren na karakter i atmosferu grada, a treći nastoji zahvatiti potencijal i transformacije. U okviru promatranja materijalnosti $i$ estetike Zagreba uvrstile smo prostorne prakse migranata, njihovo korištenje gradskog prostora i doživljaj izgleda grada. Drugi sklop usmjerava pozornost na to kako migranti opisuju karakter $i$ atmosferu grada. U ovim su se karakterizacijama grada iskristalizirali pojedini atributi koji Zagreb čine ugodnim i privlačnim mjestom života. Treće se analitičko čvorište tiče potencijala $i$ transformacija, u okviru kojeg analiziramo potencijale i pozitivne promjene koje migranti prepoznaju u suvremenom Zagrebu te u kojima sami žele biti aktivnim sudionicima ili pokretačima. Sve predodžbe grada sadrže implicitne ili eksplicitne reference na druge gradove u kojima su živjeli i kontrastiraju Zagreb i London, Kijev, Harkov, Kairo, Beč, Abidjan, Sarajevo, Pariz, Rigu, Cordobu i San Juan u Argentini, Caracas, Krakov, Nazcu, Johannesburg, Sydney, neki američki grad itd.

\section{Materijalnost i estetika}

"Jako je šarmantan. On je stara Europa, stara devetnaestostoljetna Europa. Ako zamisliš Beč, zamišljaš Zagreb. Topografski jako zanimljivo mjesto, u podnožju planine, s rijekom na drugoj strani. Izrazito je ugodan i pogodan za živjeti." 
"Sviđa nam se karakter i šarm koji stari grad donosi novome, a imate i novo, svakako. I treba imati novo da bi se podržala nova industrija i stvari koje dolaze, a vi ste pažljivi prema svojoj baštini."

"Zgodan mali grad. (...) Lako se kreće gradom, sve je unutar 15 - 20 minuta."

"Lijep grad, baš lijep. Miran. Mislim da Zagreb diše. Ima puno javnih prostora i puno zelenih prostora i to je lijepo. (...) Mislim da grad radi, funkcionira kao grad."

"Po mjeri čovjeka, kako sam već rekao, možeš obaviti puno stvari hodajući. U prvo sam vrijeme šetao i zato znam da ima dosta stuba. Dakle, to je ugodan grad."

Izgled, materijalnost i estetika grada posljedica su političkih procesa, ekonomskih interesa i kulturnih dominacija; grad je "materijalizirana i izgrađena moć" (Frers i Meier 2007:2), djelo, oeuvre (Lefebvre, u Frers i Meier 2007). Migrantske slike grada posljedica su toga "procesa ispisivanja" grada kao i "određenog tipa čitateljskog iskustva" koje osoba upisuje u grad u susretu s konkretnim mjestima (Meier 2007:120).

Međunarodni migranti u Zagrebu prije svega primjećuju povijesnu arhitekturu, zelenilo, gradski promet i mogućnost pješačenja. Dobra gradska povezanost, osobito tramvajima kao specifičnim zagrebačkim prometnim sredstvom, ističe se kao prednost, uz napomenu da je užim pa i širim središtem Zagreba moguće hodati. Oboje omogućuje onim migrantima koji stanuju u širem središtu lagano i brzo svladavanje udaljenosti i čine automobil nepotrebnim. Neki koriste bicikl, primjećujući kako se tijekom godina znatno popravila biciklistička infrastruktura.

Nadalje, bez iznimke, kroz svoje parkove i zelenilo Zagreb se slika pozitivnim bojama: Jarun, Bundek, Maksimir, Sljeme, manji parkovi i dječja igrališta omiljena su mjesta rekreacijskih aktivnosti i provođenja slobodnog vremena većine migranata, bez obzira na razlike među njima. Svaki tip zelene površine nalazi svoje korisnike, bilo da je riječ o reprezentativnom parku u središtu grada ili neuglednom dječjem igralištu negdje izvan središta. Neki stanovnici obronaka Medvednice ili Britanca istraživat će šetačke staze prema gradu, usput otkrivajući da je Zagreb i grad stuba. 
Povijesna arhitektura iz razdoblja vladavine Austro-Ugarske Monarhije zajedničko je mjesto migrantskih predodžbi o gradu. To s jedne strane govori o opsegu njihova kretanja i usmjerenosti na središnje donjogradske ulice, te poznavanju užeg središta nauštrb drugih dijelova grada. S druge, i oni koji poznaju druge dijelove grada ili u njima čak i stanuju također ističu "šarm" Zagreba kao "staroga europskog grada". Stoga se može reći da se ta specifična materijalnost Zagreba nameće kao opće mjesto migrantskih slika o gradu što postoji izvan konkretnih susreta s njime. Reference na Beč prisutne su i kod onih koji nisu podrijetlom iz Austrije, a isticanje i zadivljenost "europskom ljepotom" grada izrazitije je među migrantima izvaneuropskog ili istočnoeuropskog podrijetla. Neki od njih, ovisno o mjestu iz kojeg dolaze, imaju specifične komentare na "kaotičnost" nekih novijih dijelova grada, svjedočeći o konstruiranosti slika grada na razmeđu njegove materijalnosti i migrantove perspektive.

\section{Karakter i atmosfera}

"Osjećam se ugodno u Zagrebu. Osjećam ga kao dom."

"Obožavam što je intiman, hodaš ulicama i srećeš iste ljude."

"Siguran je. Lijepo je vidjeti žene same noću, onda znaš da je siguran. U Londonu postoji daleko veći pritisak, više kontakata s ljudima. Zagreb ima sve što želiš, ali ako si društveno dosta aktivan, brzo ćeš pokriti sva glavna mjesta. Ima dobru i lošu stranu. Ovdje postaneš prisan $\mathrm{s}$ ljudima, mjestima. U Londonu je tempo puno brži, promjene..."

"Kad smo ovamo došli, grad nam se uistinu svidio. To je i jedan od glavnih razloga zašto smo ostali. Mogu hodati u jednom smjeru i ne vidjeti nikoga, a onda hodati u drugom smjeru i vidjeti tisuće ljudi. To je ta ljepota, najbolje iz oba svijeta: Zagreb je istovremeno i tih i užurban."

"U isto je vrijeme i jako miran. Nakon Harkova, koji ima dva milijuna ljudi, 700000 je prekrasna količina. U jedan je trenutak i jako živa metropola. Kazališta i svi ti koncerti, prekrasan socijalni život. I miran. Ova kombinacija, grad ima ravnotežu i sve oznake glavnog grada, europske metropole. A u isto vrijeme s puno zelenila. (...) Tako da je ova kombinacija metropole za mene jedna od najboljih u Europi. (...) A tu je ta kombinacija kad je ekologija kao na moru, u malom gradu, a život kao u velikom gradu. Imaš sve u jednom." 
Atributi karaktera i gradske atmosfere dominantno su vezani uz njegovu veličinu: Zagreb je "malen", "intiman” i "prisan”. Percipiraju se - i u izvanposlovnim kontekstima cijene - njegova opuštenost, sporost i sigurnost, značenja koja se uobičajeno pripisuju malim mjestima ili prošlosti. Sukus nekih od tih atributa možda je najbolje izražen opaskama međunarodnih migranata o lokalnom pijenju kave. Nakon prvotnog iznenađenja zbog navike građana da polako i višekratno konzumiraju kavu, shvatili su kako nije riječ o zadovoljavanju biološke potrebe nego o društvenoj aktivnosti, pri kojoj se mogu sklapati i poslovni dogovori.

Zagreb se doživljava kao "građanski” grad. Ta percepcija upućuje na izvjestan tip zagrebačke kulture kontrastirane s gustoćom i kaosom afričkog grada, drugačijom “dušom” grada s otomanskim naslijeđem ili neurednošću južnoameričkog grada. Javlja se i nostalgična percepcija grada kao "dragulja" nedodirnuta turizmom ili, zbog nedovoljne turističke promocije, slika "tajnovitog" mjesta sa "skrivenim blagom" koje ima moć da iznenadi. "Sporost" i "uspavanost" ponekad se interpretiraju i kao zamrznutost u vremenu i zaostajanje za nekim aspektima modernih gradova.

$\mathrm{U}$ očima međunarodnih migranata Zagreb je prepun ambivalencija i kontrasta: istodobno "tih i užurban", "malo-veliko selo", "malen, ali ima sve", dovoljno velik da omogućuje anonimnost, no istodobno dovoljno malen da se uspostavi prisnost, koju smo već spomenule kao važan element inkorporacije migranata u grad. Zagreb tako spaja razne svjetove, i uzima "najbolje iz oba svijeta", pri čemu se misli na užurbanost i gužvu velegrada s jedne strane, te, s druge, uspavanost i mir sela. Mogle bismo zaključiti da je Zagreb glavni grad bez obilježja glavnog grada. Ukratko, nesvodiv isključivo na jedno od obilježja koja mu se pripisuju, neukalupljiv u jednostrane atribucije. Kako je znakovito kazao jedan mladić: "On je samo Zagreb!"

\section{Potencijal i transformacije}

"Mislim da ima puno potencijala."

"Htio sam se društveno angažirati da vidim što mogu učiniti, ali to je u to doba [2011.] bio problem jer je sve bilo na hrvatskom." 
"Kreće se, kao spirala je, kreće se. Mjesta, lokali, nastaju, nestaju. Ako bilo kamo odeš, vidiš što je tamo i onda se vratiš nakon mjesec dana i pola biznisa je nestalo. Zamijenjeni su, uglavnom se otvaraju pekarnice i mjesta za kavu."

"Ja vidim da smo mi na pravom mjestu u pravo vrijeme. Hrvatski turizam trenutno ide fenomenalno. Ja pratim sve statističke brojke, ja pratim količinu turista svake godine, količinu po mjestima. Novi aerodrom. I ovo su sve oznake jakog trenda."

"Postaje sve više i više kozmopolitski. Tako ja to doživljavam. (...) U radnom iskustvu Zagreb mi puno znači. I to što sad postaje sve više i više kozmopolitski. I to što će tek sad krenuti. To puno znači. Znači, sad je stvarno vrijeme za biti ovdje."

"Na primjer, Beč ili London već su na vrhu gastroscene, a Hrvatska još nije. I kad raste trend, to je najbolja situacija, bolja nego da si tamo na već punom tržištu. A mi još imamo puno koncepata koji tu ne postoje. Ja znam kojih koncepata ima u svijetu i u Ukrajini, tako da ih mogu primijeniti."

"Imate potencijal, imate ljude, imate sve, ali ih gušite šokantnim porezima!"

"Strancima je jako teško pokrenuti biznis u Hrvatskoj. To je jedino što mi se ne sviđa u Hrvatskoj. Sve države, sve zemlje europske jako su dobre za biznis i investicije. Ako netko dolazi s novcem, svi otvaraju vrata, osim u Hrvatskoj. Hrvatska je napravila sve da bi to bilo preteško. Na svakoga zaposlenog stranca moraš uzeti nekoliko Hrvata... (...) Strancima nije lako. Oni trebaju raditi puno više da bi zadobili povjerenje kakvo ima Hrvat prema Hrvatu. Tako da stranci za isti rezultat trebaju raditi dva ili tri puta više od Hrvata."

Migrantski se doživljaji Zagreba manje referiraju na gradsku suvremenost i potencijal. Kako to pokazuju kazivanja vezana uz materijalnost i karakter grada, njihovi su dojmovi grada pretežno ukotvljeni u prošlosti: percipiraju ga kao sporo mijenjajući grad prošlosti. Vrednovanje ovisi i o tome s kojim je motivom migrant došao u grad, odnosno što ovdje radi ili želi raditi. Oni koji planiraju ili su ostvarili neku poduzetničku aktivnost, a dolaze iz užurbanih i dinamičnih megagradova Zapadnog svijeta, kritični su prema navodno omiljenom lokalnom komentaru na neku njihovu ideju ili sugestiju - "polako, polako". 
Drugi su percipiranu tradicionalnost grada i stanovnika prihvatili kao pozitivnu, no željeli su unijeti promjene i upravo u vlastitom angažmanu na promjenama i inoviranju vidjeli su svoju poduzetničku šansu. Brendiranje grada kao turističke destinacije i posljedično restrukturiranje ugostiteljskog sektora prepoznalo je nekoliko sugovornika kao mogućnost za razvoj svojih poslova. Migranti u Zagrebu stoga se mogu smatrati akterima repozicioniranja grada na međunarodnoj skali gradova. Međunarodni migranti, kao i Hrvati s međunarodnim iskustvom, predvodnici su širenja tzv. etnogastronomske ponude (npr. korejska, šrilankanska, argentinska, indijska, bliskoistočna, francuska hrana), inovativnih koncepcija kao što su street food restorani i proizvodnja craft piva, ili pak otvaranja maloprodajnih trgovina s namirnicama i začinima podrijetlom iz raznih zemalja ili kontinenata (npr. trgovine azijskom, afričkom, ukrajinskom, turskom i sl. hranom). Među njima su Tetiana i njezin suprug koji su u Zagreb doselili iz Ukrajine te u sinergiji s jednim lokalnim poduzećem u rujnu 2016. otvorili restoran. Tetiana je procijenila da je trenutak bio pogodan za djelovanje, jer s jedne strane postoje nepokrivene ekonomske niše, a s druge se grad počeo intenzivno mijenjati zbog nastojanja gradskih vlasti da razviju turističku industriju. Primjer našeg sugovornika Daniela pokazuje i drugačije tendencije pozicioniranja. Daniel sa svojim prijateljem razvija projekt kojim žele hrvatske prehrambene proizvode, ono "najbolje od naše zemlje", ${ }^{18}$ plasirati u svijetu, pri čemu kao glavne kupce vide pripadnike hrvatske dijaspore. Daniel na taj način iz Zagreba u svijet želi slati one proizvode za koje je prepoznao da ih u inozemstvu nije lako pronaći.

Oni koji duže žive u Zagrebu, a riječ je o osobama koje su ovdje provele i više godina i dobro upoznale grad, primjećuju promjene, kako negativne - zatvaranje trgovina i malih biznisa, tako i pozitivne - sve raznolikiju gastronomsku ponudu. Kao oštroumni promatrač i sudionik gradskog života više od pet godina, jedan od naših sugovornika ima niz ideja vezano uz restrukturiranje postindustrijskog Zagreba: npr. smatra da ga ne treba utemeljiti samo na turizmu nego treba razmisliti i o mogućnosti privlačenja tehnološkog kapitala, o čemu govore i u uvodu spomenute smjernice za gospodarski razvitak grada Ekonomskog instituta u Zagrebu.

\footnotetext{
${ }^{18}$ https:/www.facebook.com/croatiagourmet/
} 
Da bi to uspjelo, slažu se svi sugovornici s poduzetničkim idejama, valjalo bi hrvatsko gospodarstvo osloboditi “šokantnih" poreza, bazirati na znanjima a ne "vezama", otvoriti novim idejama i ne diskriminirati mlade ljude.

Osim u novim poduzetničkim idejama, migranti se pokazuju i kao akteri na društvenoj i kulturnoj sceni. Takav je primjer Egipćanka Theresa koja je udajom za Hrvata doselila u Zagreb u srpnju 2014. godine. Budući da nije bila zadovoljna dostupnim informacijama o gradu na engleskom jeziku, sama je krenula u istraživanje i svoje opservacije o mjestima, događajima, aktivnostima, ponudi i mogućnostima u gradu počela objavljivati na svom portalu Unique Zagreb (Jedinstveni Zagreb). ${ }^{19}$ Ime portala odražava Theresin osobni osjećaj različitosti i potragu za specifičnim, jedinstvenim aspektima života u gradu, za "drugačijim" Zagrebom nego što ga nude standardne brošure i informacije orijentirane na domaće, zagrebačko i hrvatsko. Tako je između ostaloga prikazala jedan korejski i brazilski restoran (posljednji je u međuvremenu zatvoren), kinesku čajanu, trgovine bliskoistočnom i azijskom hranom i začinima, lokalne trgovine vintage predmetima i "jedinstvenim" glagoljičkim poklonima. Kompilirala je kratki praktični vodič po gradu, dostupan na portalu kao i u Facebook grupama Expats in Zagreb i Unique Zagreb Expats koje administrira. Aktivna je i putem meetup aplikacije i organizira istraživačke fotografske obilaske gradom, kuhanje i druženje uz hranu, posjete restoranima, gledanje filmova i sl., kojima obično prisustvuje manji broj ljudi, uglavnom migranata i Hrvata s internacionalnim iskustvom. Theresina potraga za "jedinstvenim" u Zagrebu u prvom je redu potraga za internacionalnim sadržajima, za alternativama od lokalnoga i nacionalnoga, za internacionalnim "krajolikom” (Appadurai 1996) koji je obilježje svjetskih prijestolnica i megagradova, u kojima su i Theresa i drugi doseljenici u Zagreb prethodno živjeli. U toj urbanoj niši ona kreira svoj "jedinstveni Zagreb", istodobno lokalni i internacionalni, sastavljen od lokalnih znanja, artefakata i podataka i internacionalnih aspekata koji rekreiraju polje različitosti na koje su migranti naučili, u kojem su se kretali u gradovima prethodnog života, od Abidjana do Kaira ili Kingstona. To je ujedno i polje poznatoga i razumijevanja u susretu s ljudima s migrantskim iskustvom, bilo da su Hrvati ili stranci, utočište u hrvatskom jezičnom okruženju.

\footnotetext{
${ }^{19} \mathrm{http}: / / w w w . u n i q u e z a g r e b . c o m$
} 
Međunarodni migranti se dakle angažiraju ili žele angažirati kao akteri ekonomskih, društvenih i kulturnih promjena i vide mogućnost da sami pridonesu povoljnom trenutku repozicioniranja Zagreba na međunarodnoj sceni. Takav je angažman rezultat dobrog poznavanja političkog, pravnog i ekonomskog sustava, društva i kulture, no ujedno je i rezultat njihova dobra obrazovanja i afektivnog odnosa prema gradu u kojem tvrde da su našli "dom", osjećaju se "domaćima" (local) i planiraju duže ostati. Međutim, neki zbog strukturnih prepreka (poteškoće pri pokretanju privatnog poduzeća, posebni uvjeti za strance, visoki porezi) odustaju od vlastitog poduzeća ili su ga prisiljeni zatvoriti i napustiti Hrvatsku.

\section{MIGRANTI, STVARANJE I (RE)SKALIRANJE GRADA}

Migranti iz srednjih društvenih slojeva u Zagrebu na različite načine stvaraju svoje mjesto u gradu i stvaraju grad. Njihove su pojedinačne priče raznolike, no odaju i slična iskustva susreta s gradom i inkorporacije u gradski život. Zagreb je za njih privremeno ili trajno mjesto života, koji postupno upoznaju sve bolje i s raznih aspekata. Materijalnost i estetika Zagreba, njegov karakter i atmosfera te potencijal i transformacije - tri su perspektive koje smo prepoznale kao čvorišta njihovih doživljaja grada. U pojašnjavanju materijalnosti Zagreba i njegova karaktera naglasili su one karakteristike grada koje prepoznaju kao njima važne, zbog kojih život u Zagrebu opisuju kao ugodan i koje po njima predstavljaju prednost Zagreba u odnosu na druge gradove, zbog kojih se u njemu odlučuju i trajnije nastaniti. Neki su od tih atributa veličina Zagreba, dobra povezanost i mogućnost pješačenja pri obavljanju svakodnevnih zadaća, sigurnost, prisnost i opuštenost. U govoru o potencijalima Zagreba prepoznali su pojedine niše kao polja mogućih transformacija grada.

Zahvaljujući svom iskustvu života u drugim zemljama, međunarodni migranti implicitno i eksplicitno uspoređuju Zagreb s drugim gradovima. Pritom ističu one njegove komparativne prednosti koje su ih potaknule na preseljenje ili učvrstile u uvjerenju da ovdje žele graditi svoj život. Pozitivni atributi koje vežu uz Zagreb daju mu prednost u odnosu na neke druge gradove u kojima su prije živjeli ili koje poznaju. Slabiju razvijenost pojedinih sektora u odnosu na druge svjetske gradove, poput gastronomske scene, prepoznaju kao potencijal i svoju priliku. Kao i trendovi u koje 
se žele uklopiti, poput razvoja zagrebačkog turizma, i ova im relativna nerazvijenost pojedinih niša, pokazuje da su "na pravom mjestu u pravo vrijeme". U ovakvim odmjeravanjima gradova migranti konstruiraju značenja Zagreba u relaciji s drugim gradovima, pozicioniranju ga prema vlastitim iskustvima, stvarajući tako vlastite, individualne skale gradova. $\mathrm{Na}$ njima Zagreb zauzima visoko mjesto.

S druge strane, gradska skala definirana neoliberalnim procesima kao artikulacija institucionalne, političke, kulturne i ekonomske moći grada (usp. Glick Schiller i Çağlar 2009, 2011) u slučaju Zagreba izrazito je niska. Nepovoljni gospodarski pokazatelji i razvojni problemi grada koje detektira studija Ekonomskog instituta (2016), kao i nepostojanje migracijske politike koja bi podala referentni okvir migracijskim kretanjima, indikatori su komparativno niske gradske skale. O toj niskoj poziciji svjedoče brojke međunarodnih migranata: u posljednjih deset godina broj osoba doseljenih iz inozemstva na godišnjoj razini tek je 2016. prešao brojku od 3000 (usp. Državni zavod za statistiku 2017).

Individualne skale migranata $\mathrm{u}$ Zagrebu stoga idu usuprot ovoj poziciji koju Zagreb ima u globalnim okvirima: usprkos tomu što Zagreb gubi u odmjeravanjima u hijerarhijama moći s drugim europskim i svjetskim gradovima, atributi njegove materijalnosti i estetike, karaktera i atmosfere te potencijala i transformacija na individualnim ga skalama svrstavaju drugačije. Prepoznajući te pozitivne atribute grada pa i razvojni potencijal koji nosi te svrstavši ga visoko na svojim individualnim skalama gradova, doseljenici ne samo da donose odluku o životu u Zagrebu nego žele biti aktivni u transformiranju grada. Neki od njih žele obogaćivati turističku ponudu, te su njihova nastojanja usporedna lokalnim naporima u reskaliranju statusa Zagreba kroz razvoj turističke industrije. Drugi imaju inovativne poduzetničke ideje, angažiraju se u organizaciji događanja i u pružanju raznolikih informacija na engleskom jeziku, ${ }^{20}$ okupljaju

\footnotetext{
${ }^{20}$ Od proljeća 2017. godine aktivne su internetske stranice Total Zagreb, koje čine dio projekta Total Croatia koji je započeo engleski pisac, ujedno i stanovnik Hrvatske, Paul Bradbury 2011. godine s ciljem informiranja turista i doseljenika, na engleskom jeziku, o poslovnim mogućnostima, turističkoj ponudi, kulturnim događanjima i slično (http:// www.total-croatia-news.com/destination-zagreb). Također, Facebook stranice koje smo analizirale živahna su mjesta razmjene informacija o različitim događanjima, proizvodima, uslugama, trgovinama, stambenim i administrativnim pitanjima i sl.
} 
druge strance u Zagrebu. Dijelom ih je na to nagnala činjenica da zbog nedovoljnog razumijevanja hrvatskog jezika i nedostatnih informacija na engleskom nisu mogli dostatno konzumirati društvene i kulturne sadržaje. Primjer angažiranja s posljedicom stvaranja novih kulturnih i društvenih niša jest i potraga Therese Khalil za "jedinstvenim Zagrebom" u kojem se isprepliće lokalno i internacionalno. Opisanim angažmanom migranti obogaćuju društvenu i kulturnu scenu Zagreba, a komunikacijom na engleskom jeziku pružaju informacije o gradskom životu i sadašnjim i možebitnim budućim doseljenicima u grad.

Oni pojedinci koji su kritični prema pojedinim aspektima gradskog života - ponajprije gospodarskim - vlastitim primjerom svjedoče o tome što bi se trebalo napraviti kako bi inkorporacija tekla lakše i kako poslovne ideje ne bi nailazile na zidove sazdane od visokih poreza i nepovoljnih zakonskih propisa. Migranti kojima je u obzorju primarno posao i privatno poduzetništvo dobro su upoznali ekonomske i poslovne aspekte života u Zagrebu i Hrvatskoj. Više od drugih, njihovi su iskazi ambivalentni: s jedne strane, kao i većina drugih osoba, oduševljeni su gradom, njegovom veličinom, srednjoeuropskom lokacijom i blizinom Jadrana, "načinom života", a s druge strane, iznimno su kritični prema mogućnostima i okolnostima poslovanja i zatvorenosti državnog sustava prema stranim investicijama srednjeg i malog dometa. Više nego u domeni neprijateljstva lokalnog stanovništva prema migrantima, u toj zatvorenosti sustava mogu se locirati sistemski aspekti institucionalne diskriminacije nacionalne države prema došljacima. Ponekad iskazima migranata dominira neuspješna potraga za poslom i valorizacijom obrazovnog kapitala i međunarodnog iskustva pa neki napuštaju grad i zemlju. Individualne gradske skale u tim se slučajevima sukobljavaju s nepovoljnim gospodarskim pokazateljima i restriktivnim poslovnim uvjetima. Zatvaranje Tetianina restorana koji smo ranije spomenule može poslužiti kao ilustracija. Činilo se kako je riječ o uspješnoj imigracijskoj priči; Tetiana je voljela živjeti u Zagrebu, maksimalno se angažirala u pripremama za preseljenje i pokretanju posla, no unatoč tomu bila je prisiljena zatvoriti restoran. Potvrdilo se upozorenje njezinih sunarodnjaka, s kojima je razgovarala o poslovnim mogućnostima i dobrim i lošim stranama života u Hrvatskoj, koji su joj kazali kako je Hrvatska "teška za biznis". Predmnijevamo da su se u ovom slučaju ostvarile "prijetnje" gospodarskoj djelatnosti u Zagrebu i 
Hrvatskoj koje je identificirala studija Ekonomskog instituta u Zagrebu, između ostaloga previsoki porezi i doprinosi, osjetljivost gospodarskih djelatnosti na recesiju, nedovoljni državni poticaji (Ekonomski institut 2016:175), a u konkretnom slučaju i činjenica da su Tetiana i suprug bili stranci, za koje su "prijetnje" uspješnom poslovanju još veće zbog znatnih zahtjeva pri osnivanju trgovačkog društva ili obrta. U ovakvim slučajevima strukturni i institucionalni aspekti koji Zagreb svrstavaju nisko na skali gradova pokazuju se kao jači od individualnih skala te unatoč entuzijazmu pojedinaca mogu dovesti do razočaranja i u krajnjem slučaju i odlaska iz Hrvatske. Drugim riječima, potencijal i transformacije koje su migranti prepoznali u Zagrebu, zbog nepovoljnih strukturnih uvjeta poslovanja, ipak se ne ostvaruju. Time je ujedno onemogućeno i ispunjavanje punog potencijala migranata kao aktera (re)skaliranja grada.

Taj potencijal obrazovanih doseljenika iz srednjih društvenih slojeva nije detektiran u domeni javnih politika, ni nacionalnih, ni lokalnih. Integracijski dokumenti i politike ih ne spominju ili ih spominju rubno, mnogo veći naglasak stavljajući na ranjive skupine stranaca - izbjeglice, tražitelje azila, azilante i strance pod supsidijarnom zaštitom. O nedovoljnoj pozornosti koja se pridaje temi migracija općenito govori i to što ona nije zastupljena u programima političkih stranaka. Tek nešto veću pozornost $\mathrm{u}$ političkoj domeni dobivaju hrvatski iseljenici i njihovi potomci. ${ }^{21}$ Govor o strancima na taj je način u javnom diskursu usmjeren ili prema ranjivim skupinama, pri čemu Hrvatska svoju poziciju gradi u odnosu sa širim politikama Europske unije, ili prema strancima hrvatskog podrijetla koji su dio nacionalnog diskursa i političkih retorika. Usto, da stranci nisu dovoljno prepoznati u javnim politikama i postupcima prepoznajemo i u administrativnim poteškoćama o kojima su nam svjedočili naši sugovornici, $\mathrm{u}$ nedostupnosti informacija na engleskom jeziku te u poteškoćama $\mathrm{u}$

\footnotetext{
${ }^{21}$ Opažanja temeljimo na analizi dokumenata javnih politika koji se tiču boravka stranaca u Republici Hrvatskoj i analizi medijskog diskursa koje smo provele u okviru projekta Stvaranje grada: prostor, kultura i identitet te na višegodišnjem kontinuiranom praćenju javnog diskursa, medija, stručnih i znanstvenih rasprava. Jasna Čapo godinama se kontinuirano bavi hrvatskim iseljenicima i njihovim potomcima koji doseljavaju u Hrvatsku te je na osnovi svojih istraživanja objavila niz znanstvenih radova; usp. primjerice Čapo et al. 2014.
} 
sporazumijevanju kroz koje su pojedinci prolazili. Što se pak tiče pozicije migranata u Zagrebu, na osnovi toga što nacrt gradske strategije razvoja do 2020. godine ne spominje migracije obrazovanih stručnjaka i općenito srednjih slojeva (usp. Gradski ured za strategijsko planiranje i razvoj Grada 2017), u koje spada većina naših sugovornika, zaključujemo kako ni na gradskoj razini nisu prepoznati kao potencijalni čimbenik razvoja. To je u suprotnosti s njihovim prepoznavanjem Zagreba kao poželjnog mjesta života, s potencijalom i mogućnostima transformacija, i njegovim svrstavanjem visoko na vlastitim individualnim skalama gradova.

\section{LITERATURA I IZVORI}

AMIT, Vered. 2007. "Structures and Dispositions of Travel and Movement". U Going First Class? New Approaches to Privileged Travel and Movement, ur. Vered Amit. New York - London: Berghahn Books, 1-14.

ANDREOTTI, Alberta, Patrick LE GALÈE i Francisco Javier MORENO-FUENTES. 2015. Globalised Minds, Roots in the City. Urban Upper-Middle Classes in Europe. Chichester: Wiley Blackwell.

APPADURAI, Arjun. 1996. Modernity at Large. Cultural Dimensions of Globalization. Minneapolis: University of Minnesota Press.

BAUMAN, Zygmunt. 2000. Liquid Modernity. Cambridge: Polity Press.

BEAVERSTOCK, Jonathan. 2005. "Transnational Elites in the City: British HighlySkilled Inter-Company Transferees in New York City's Financial District". Journal of Ethnic and Migration Studies, vol. 31/2:245-268. https://doi. org/10.1080/1369183042000339918

BENSON, Michaela i Karen O'REILLY. 2009. "Migration and the search for a better way of life: a critical exploration of lifestyle migration". The Sociological Review, vol. 57/4:608-625. https://doi.org/10.1111/j.1467-954X.2009.01864.x

CONRADSON, David i Alan LATHAM. 2005. "Friendship, Networks and Transnationality in a World City: Antipodean Transmigrants in London". Journal of Ethnic and Migration Studies, vol. 31/2:287-305. https://doi. org/10.1080/1369183042000339936

Croatia Gourmet. Facebook.com. https://www.facebook.com/croatiagourmet/_(pristup 30. 8. 2017.).

ÇAĞLAR, Ayşe i Nina GLICK SCHILLER, 2011. "Introduction. Migrants and Cities”. U Locating Migration. Rescaling Cities and Migrants, ur. Nina Glick Schiller i Ayşe Çağlar. Ithaca - London: Cornell University Press, 1-19. 
ČAPO, Jasna. 2012. “"The world is my oyster'. Well-educated Australian-Croatian citizens in the era of global mobilities". Croatian Studies Review, vol. 8/1:91-112. http:// hrcak.srce.hr/102749

ČAPO, Jasna, Caroline HORNSTEIN TOMIĆ i Katica JURČEVIĆ, ur. 2014. Didov san. Transgranična iskustva hrvatskih iseljenika. Zagreb: Institut za etnologiju i folkloristiku - Institut društvenih znanosti Ivo Pilar.

ČAPO, Jasna. (u tisku). 'Economic activities and agency of 'love-driven' international migrants in the city of Zagreb". U Contemporary Migration Trends and Flows on the Territory of Southeast Europe, ur. Marijeta Rajković Iveta, Petra Kelemen i Drago Župarić-Iljić. Zagreb: FF Press.

Državni zavod za statistiku Republike Hrvatske. 2017. Migracija stanovništva Republike Hrvatske u 2016. Zagreb: Državni zavod za statistiku Republike Hrvatske. https:// www.dzs.hr/Hrv_Eng/publication/2017/07-01-02_01_2017.htm_(pristup 30.8. 2017.).

Ekonomski institut, Zagreb. 2016. Polazne osnove za izradu Strategije razvoja Urbane aglomeracije Zagreb - gospodarski aspekti. Zagreb: Ekonomski institut, Zagreb. http://www.zagreb.hr/UserDocsImages/arhiva/PRILOZI\%20EIZFINAL-310516-2.pdf(pristup 30. 8. 2017.).

FAVELL, Adrian. 2008. Eurostars and Eurocities. Free Movement and Mobility in an Integrating Europe. Malden - Oxford - Carlton: Blackwell Publishing.

FAVELL, Adrian, Miriam FELDBLUM i Michael Peter SMITH. 2009. "The Human Face of Global Mobility: A Research Agenda". U The Human Face of Global Mobility. International Highly Skilled Migration in Europe, North America and the Asia-Pacific, ur. Michael Peter Smith i Adrian Favell. New Brunswick - London: Transaction Publishers, 1-25.

FECHTER, Anne-Meike. 2007. Transnational Lives: Expatriates in Indonesia. London: Routledge.

FRERS, Lars i Lars MEIER. 2007. "Encountering Urban Places - Visual and Material Performances in the City". U Encountering Urban Places. Visual and Material Performances in the City, ur. Lars Frers i Lars Meier. Hampshire - Burlington: Ashgate, 1-7.

GLICK SCHILLER, Nina. 2012. “A Comparative Relative Perspective on the Relationships Between Migrants and Cities”. Urban Geography, vol. 33/6:879-903. https://doi. org/10.2747/0272-3638.33.6.879

GLICK SCHILLER, Nina i Ayşe ÇAĞLAR. 2009. "Towards a Comparative Theory of Locality in Migration Studies: Migrant Incorporation and City Scale". Journal of Ethnic and Migration Studies, vol. 35/2:177-202. https://doi. org/10.1080/13691830802586179

GLICK SCHILLER, Nina i Ayşe ÇAĞLAR, ur. 2011. Locating Migration. Rescaling Cities and Migrants. Ithaca - London: Cornell University Press, 2011. 
GLICK SCHILLER, Nina i Ayşe ÇAĞLAR. 2013. "Locating Migrant Pathways of Economic Emplacement: Thinking Beyond the Ethnic Lens". Ethnicities, vol. 13/4:494-514. https://doi.org/10.1177/1468796813483733

Gradski ured za strategijsko planiranje i razvoj Grada. 2012. ZagrebPlan. Razvojna strategija Grada Zagreba. Ciljevi i prioriteti razvoja do 2020. Zagreb: Gradski ured za strategijsko planiranje i razvoj Grada. http://www.zagreb.hr/UserDocsImages/ arhiva/zgplan/zagrebplan-ciljevi_i_prioriteti_razvoja_do_2020.pdf_(pristup 30.8. 2017.).

Gradski ured za strategijsko planiranje i razvoj Grada. 2015a. Demografska kretanja $i$ pokazatelji funkcionalne povezanosti na području urbane aglomeracije Zagreb - podloga za izradu Strategije razvoja urbane aglomeracije Zagreb. Zagreb: Gradski ured za strategijsko planiranje i razvoj Grada. http://www.zagreb. $\mathrm{hr} /$ UserDocsImages/arhiva/Demografska\%20studija\%20za\%20potrebe $\% 20$ Strategije\%20razvoja\%20UAZ_2015..pdf_(pristup 30. 8. 2017.).

Gradski ured za strategijsko planiranje i razvoj Grada. 2015b. ZagrebPlan 2020+. Razvojna strategija Grada Zagreba. Radni materijal_studeni 2015. Vizija $i$ strateški ciljevi. Prioriteti i mjere. Zagreb: Gradski ured za strategijsko planiranje i razvoj Grada. http://www.zagreb.hr/UserDocsImages/arhiva/ZAGREBPLAN\%20 2020 prioriteti_mjere_radno.pdf_(pristup 30.8.2017.).

Gradski ured za strategijsko planiranje i razvoj Grada. 2016. Statistički ljetopis Grada Zagreba 2016. Zagreb: Gradski ured za strategijsko planiranje i razvoj Grada. http://www1.zagreb.hr/zgstat/ljetopis2015.html_(pristup 30. 8. 2017.).

Gradski ured za strategijsko planiranje i razvoj Grada. 2017. Nacrt Strategije razvoja Urbane aglomeracije Zagreb. Verzija_2. 30. lipnja 2017. Prijedlog za javnu raspravu. Zagreb: Gradski ured za strategijsko planiranje i razvoj Grada. http:// www.zagreb.hr/UserDocsImages/arhiva/strategijsko_planiranje/Nacrt\%20 Strategije.pdf (pristup 30. 8. 2017.).

GRGURINOVIĆ, Ivona. 2013. "Putnici i statisti: o politici (akademske) mobilnosti”. Studia ethnologica Croatica, vol. 25:129-142. http://hrcak.srce.hr/112105

GULIN ZRNIĆ, Valentina. 2009. Kvartovska spika. Značenja grada i urbani lokalizmi u Novom Zagrebu. Zagreb: Institut za etnologiju i folkloristiku - Naklada Jesenski i Turk.

HORNSTEIN TOMIĆ, Caroline. 2014. “'Ovdje sam vječno Švabica’: o izgradnji identiteta u kontekstu migracijskih procesa”. U Didov san. Transgranična iskustva hrvatskih iseljenika, ur. Jasna Čapo, Caroline Hornstein Tomić i Katica Jurčević. Zagreb: Institut za etnologiju i folkloristiku - Institut društvenih znanosti Ivo Pilar, $109-131$.

HORWATH HTL. 2011. Strategija turističkog brendiranja grada Zagreba s planom promocije na međunarodnom tržištu. Konačni izvještaj. http://www.infozagreb.hr/ documents/b2b/TZGZ-Branding-FINAL-291211.pdf (pristup 30. 8. 2017.). 
HORWATH HTL. 2016. Strateški i operativni marketinški plan TZGZ 2017.-2020. Prezentacija. http://www.infozagreb.hr/documents/b2b/strateskioperativniplan. pdf (pristup 30. 8. 2017.).

Kiosk. YouTube.com. https://www.youtube.com/channel/ UCwwaMYUbsqSFffxYlpV9_6w (pristup 30. 8. 2017.).

LEVITT, Peggy i Nina GLICK SCHILLER. 2004. "Conceptualizing Simultaneity: A Transnational Social Field Perspective on Society". International Migration Review, vol. 38/3:1002-1039. https://doi.org/10.1111/j.1747-7379.2004.tb00227.x

Lijepa naša vaša. tportal.hr. https://www.tportal.hr/tag/lijepa-nasa-vasa (pristup 30. 8. 2017.).

McCLAIN BROWN, Cody. 2016. Propuh, papuče \& punica. Vodič za preživljavanje u Hrvatskoj. Zagreb: Algoritam.

MEIER, Lars. 2007. "Working in the Skyline - Images and Everyday Action". U Encountering Urban Places. Visual and Material Performances in the City, ur. Lars Frers i Lars Meier. Hampshire - Burlington: Ashgate, 119-134.

MEIER, Lars, ur. 2015. Migrant Professionals in the City. Local Encounters, Identities and Inequalities. New York - London: Routledge.

Migracijska politika Republike Hrvatske za razdoblje 2013. - 2015. godine. NN 27/2013, http://narodne-novine.nn.hr/clanci/sluzbeni/full/2013_03_27_456.html (pristup 30. 8. 2017.).

NOWICKA, Magdalena. 2006. Transnational professionals and their cosmopolitan universes. Frankfurt/Main - New York: Campus-Verlag.

SMITH, Michael Peter i John EADE. 2009. "Transnational Ties: Cities, Migrations, and Identities". U Transnational Ties: Cities, Migrations, and Identities, ur. Michael Peter Smith i John Eade. New Brunswick - London: Transaction Publishers, 3-13.

Stranci, a naši. Hrt. https://hrti.hrt.hr/video/show/1788560/stranci-a-nasi-dokumentarnifilm_(pristup 30. 8. 2017.).

Total Zagreb. http://www.total-croatia-news.com/destination-zagreb_(pristup 30. 8. 2017.).

Unique Zagreb. http://www.uniquezagreb.com_(pristup 30. 8. 2017.).

VERTOVEC, Steven. 2007. "Super-diversity and its implications". Ethnic and Racial Studies, vol. 30/6:1024-1054. https://doi.org/10.1080/01419870701599465

Zakon o strancima. NN 130/2011, http://narodne-novine.nn.hr/clanci/ sluzbeni/2011_11_130_2600.html, NN 74/2013, http://narodne-novine.nn.hr/ clanci/sluzbeni/2013_06_74_1475.html_(pristup 30.8.2017.). 


\section{ZAGREB THROUGH THE EYES OF INTERNATIONAL MIGRANTS: MEANINGS, POTENTIALS AND (RE)SCALING OF THE CITY}

Within the framework of migration research on the mechanisms of migrant integration in their host cities and their impact on the rescaling of cities, this paper analyses the meanings of the city as constructed by international middle-class migrants in Zagreb. The paper equally examines how migrants position Zagreb in their personal ranking of cities based on the perceived attributes of Zagreb and in comparison with other cities. The individual assessments are further weighed against the position Zagreb holds as a migration destination according to the economic and social indicators. The paper also explores the potential of migrants for repositioning and rescaling the city within global urban hierarchies.

Keywords: international migration, urban anthropology, Zagreb, scaling of the city 